\title{
DEBT, STRUCTURAL ADJUSTMENT, AND NON-GOVERNMENTAL ORGANIZATIONS: A CROSS-NATIONAL ANALYSIS OF MATERNAL MORTALITY
}

\author{
John M. Shandra \\ Department of Sociology \\ State University of New York at Stony Brook \\ jshandra@notes.cc.sunysb.edu \\ Carrie L. Shandra \\ Department of Sociology \\ Hofstra University \\ carrie.alexandrowicz@hofstra.edu \\ Bruce London \\ Department of Sociology \\ Clark University \\ blondon@clarku.edu
}

\begin{abstract}
We begin this study by considering dependency theory claims regarding the harmful influence of both debt and structural adjustment on maternal mortality. We expand upon previous research by conducting the first cross-national study to examine the impact of health and women's non-governmental organizations on maternal mortality. In doing so, we use lagged dependent variable panel regression for a sample of sixty-five poor nations. We find substantial support for dependency theory that higher levels of debt service, structural adjustment, and multinational corporate investment are associated with increased maternal mortality. Initially, we find no support for world polity theory that health and women's non-governmental organizations are significantly related to maternal mortality. However, we respecify our original models in order to test the idea that democratic nations provide a "political opportunity structure" that improves the ability of health and women's non-governmental organizations to deliver health and other social services. We find substantial support for this hypothesis. The results indicate that both health and women's non-governmental organizations are associated with decreased maternal mortality in nations with higher levels of democracy than in nations with lower levels of democracy. We conclude with a discussion of the findings, theoretical implications, methodological implications, policy implications, and potential directions for future research.
\end{abstract}

Copyright @2010, American Sociological Association, Volume XVI, Number 2, Pages 217-245 ISSN 1076-156X 


\section{INTRODUCTION}

The World Health Organization (2007) estimates that the total maternal deaths in 2005 was 536,000. This means that 400 women worldwide die per 100,000 live births. However, an overwhelming majority of these deaths occur in the poor nations of the world. The maternal mortality ratio in poor nations is equal to 450 deaths per 100,000 live births (e.g., 533,000 total maternal deaths) compared to just 9 deaths per 100,000 live births in the rich nations (World Health Organization 2007).

According to dependency theory, debt repayment and structural adjustment may partially help to explain why maternal mortality is so high in poor nations. Debt service drains already scarce capital away from investment by the government, which reduces spending on public health and other social service programs (George 1992). Similarly, structural adjustment requires nations to cut government spending to correct budgetary imbalances (Peet 2003). This too usually involves cuts in the health, education, and other welfare spending and may lead to increased maternal mortality.

Despite these apparent linkages, cross-national research has yielded some contradictory findings. Shen and Williamson (1999) find that debt service is associated with increased maternal mortality. However, they do not include a measure of structural adjustment in their analysis. Buchman (1996) finds no relationship among debt service, structural adjustment, and maternal mortality. She attributes this finding to the maternal mortality data only being available at one time point for a limited number of nations.

This study reconsiders and expands on existing research in several ways. First, we consider the dependency theory claims concerning the influence of both debt and structural adjustment on maternal mortality. In doing so, we use the most recent data available on maternal mortality from the World Health Organization (2006), which are available for a larger number of nations. However - because debt and structural adjustment reduce the ability of governments to provide social services for their populations - it has been argued by world polity theory that nongovernmental organizations have taken greater responsibility in delivering health services in poor nations (Inonue and Drori 2006; Boli and Thomas 1999; Bratton 1989). As such, nongovernmental organizations, especially health and women's non-governmental organizations, should be correlated with decreased maternal mortality (Mercer et al. 2006, Mercer et al. 2004). However, this claim has yet to be empirically examined in a cross-national context. We address this gap in the literature by conducting the first cross-national study that considers the impact of both health and women's non-governmental organizations on maternal mortality.

We now turn to a review of dependency theory predictions about debt and structural adjustment. We then consider world polity hypotheses about health and women's nongovernmental organizations. Next, we elaborate upon the reasons for including other theoretically relevant predictors in the cross-national models (e.g., gross domestic product per capita, economic growth, education, democracy, public health expenditures, domestic investment, multinational corporate investment, and total exports.). Finally, we conclude with a discussion of the findings, some policy implications, and possible directions for future research. 


\section{DEPENDENCY THEORY: DEBT AND STRUCTURAL ADJUSTMENT}

The dependency perspective argues that international economic exchanges and unequal power relationships between rich and poor nations are detrimental to the poor nations of the world. ${ }^{1}$ In essence, rich nations become wealthy by exploiting the cheap labor and resources of poor nations (e.g., Evans 1979, Amin 1976; Frank 1967). In recent years, a substantial body of cross-national research has been published in an attempt to provide empirical tests of different propositions drawn from dependency theory. Some of the earliest cross-national studies in this tradition tended to incorporate measures of dependency based upon export partner concentration and commodity concentration (e.g. Moon and Dixon 1985). The cross-national research focusing on a later period tended to focus on dependence upon multinational corporations (e.g., Lena, and London 1993; London and Williams 1988; London 1988; Bornschier and Chase-Dunn 1985). A different, more recent strand of cross-national research shifts the focus to various types of dependency, generated by the debt crisis especially the impacts of debt service and structural adjustment lending (e.g., Buchman 1996; Bradshaw et al. 1993; Bradshaw and Wahl 1991; Walton and Ragin 1990). Our study follows in the debt and structural adjustment tradition.

From above, dependency theory hypothesizes that high levels of foreign debt adversely affect health in poor nations (e.g., George 1992). The effects are typically linked to several factors. First, debt and interest payments drain already scarce capital and, as a result, inhibit economic development. The resulting capital drain reduces government spending on social, educational, and health programs, slowing any decline in mortality (Shen and Williamson 1999). This capital drain reduces the strength and flexibility of the government, making it difficult to take action when faced with social or economic crises. We note earlier that cross-national research has yielded contradictory findings regarding the effect of debt on maternal mortality.

Moreover, the "debt crisis" highlighted an inability of many poor nations to generate enough revenue to make payments on large foreign debts. The International Monetary Fund and World Bank responded to this problem by providing structural adjustment loans designed to resolve the balance-of-payment issues by rescheduling payments, renegotiating loan terms, and providing new loans (McMichael 2004). However, these new loans required indebted nations to adopt a variety of economic policy reforms in return for the money (Rich 1994). These austerity measures include devaluing currency, reducing government spending, liberalizing trade, and privatizing government assets (Peet 2003). The underlying logic behind these reforms is an attempt to stimulate economic growth and generate hard currency for debt repayment by increasing exports and decreasing spending (George 1992). While the "earn more" and "spend less" model may facilitate debt repayment, it also has the potential to increase maternal mortality in several ways.

First, structural adjustment loans usually require deep cuts in government spending to correct for budgetary imbalances (Barbosa 2001). The nature of the cuts has varied from nation to nation, but a common theme has been the reduction in the budgets and staffs of healthcare facilities (Mohan 2001). In other words, structural adjustment weakens the capacity of governments to provide healthcare services. For example, Cliff (1991) argues that government spending cuts led Mozambique to become highly dependent on foreign aid to fund health services

\footnotetext{
${ }^{1}$ In contrast, Bhagwati (2004) offers a detailed account of why economic globalization should benefit poor nations.
} 


\section{DEBT, NGOS, AND MORTALITY 220}

for its population. Therefore, donor agencies have become increasingly influential in healthcare policy making. This has led to an emphasis on regional projects rather than national programs (Buchman 1996). This "fragmented" or "patchwork" approach delays the establishment of a stable primary healthcare system (Bryant and Bailey 1997).

It is also important to note that budgetary cuts reduce or eliminate government subsidies for social services (Rudel 2005). This tends to increase the cost of health services and medication, thereby "pricing out" most people from basic care. It also severely impacts women. The removal of subsidies increases women's unpaid labor. When subsidized childcare is cut, for example, women provide free childcare for their families and neighbors. Further, women care for those who would otherwise have been hospitalized. The additional workloads tend to keep girls from attending school, which is a key factor associated with decreasing maternal mortality (Dankelman and Davidson 1988).

Second, structural adjustment programs require that governments promote economic activity consonant with their "comparative advantage" (Peet 2003). Put differently, nations attempt to increase export earnings in order to finance interest and principal payments (McMichael 2004). The most common way to achieve this is currency devaluation, which creates a demand for a nation's exports on the world market (Mohan 2001). With currency devaluations, however, the cost of drugs and medical supplies, which are imported from rich nations, substantially increases (Peet 2003). This reduces access for most of a nation's population. Similarly, currency devaluations make imported food more expensive (Rich 1994).

This also has specific implications for women. Higher food costs tend to be born by women in the household. Since food generally goes to men first and less food is available for children, women may compensate by eating only once a day and limiting their protein intake to only once a week (Dankelman and Davidson 1988). Consequently, malnutrition and anemia increase along with women's susceptibility to illness and pregnancy complications-both factors that contribute to maternal mortality (Buckingham-Hatfield 2000).

Many poor nations also meet increased demand created from the currency devaluations by expanding production and extraction for export, which may also increase maternal mortality (Rich 1994). The sectors targeted include logging, mining, ranching, and large-scale agriculture (McMichael 2004). The export of these primary products aggravates the gap between rich and poor nations. This is because the exchange of raw materials for manufactured goods is inherently unequal and the prices for primary products have experienced long-term declines relative to the price of manufactured goods (Frank 1967). The ability of the government to raise revenues is weakened. The resulting lack of revenue affects the funding of many health and social service programs, which could increase maternal mortality. The shift to large-scale agriculture also reduces the amount of staple crops being grown for consumption, which has the potential to increase women's malnutrition (Bryant and Bailey 1997).

Third, structural adjustment loans require governments to liberalize trade by removing barriers to foreign investment. This involves a variety of regulatory concessions and financial incentives (McMichael 2004). It also involves the selling off or privatizing of government assets (Rich 1994). The most notable financial incentives are "tax holidays" that involve exemptions of export duties, import duties, and corporate income taxes (Leonard 1988). Some common regulatory concessions include eliminating the minimum wage and "imposing political stability" (e.g., outlawing of strikes, protests, and unions or firing workers at will) (Shandra, London, and 
Ross 2003). The purpose of the regulatory concessions and financial incentives is to stimulate investment within a nation to generate currency to meet debt payment obligations (Clapp 1998).

However, such regulatory concessions and economic incentives may translate into increased maternal mortality. Tax breaks and selling off of public enterprises may yield additional reductions in social service spending by eroding a nation's tax base because there is little new revenue being collected by the government (George 1992). This hampers the capacity of governments to provide health services, which are already limited by mandated cuts noted above (Buchman 1996). The privatization of government services also means that costs for the services increase, which limits access to only a small segment of a population. Moreover, foreign investors tends to repatriate most of their profits and displace local business, which slows economic growth within a poor nation and decreases money available for investment by the government in health and other social services that have the potential to reduce maternal mortality (Jorgenson 2009; Evans 1979). Finally, imposed political stability measures (e.g., outlawing strikes, protests, and unions) limit the power and prevalence of non-governmental organizations, social movements, and concerned citizens to pressure governments to provide basic social services that are lacking (e.g., healthcare, education, and sanitation) — see below for a complete discussion of how non-governmental organizations work to reduce maternal mortality (Ross and Trachte 1990).

Trade liberalization involving foreign investment by multinational corporations also has specific implications for women. It tends to generate some higher paying jobs (London and Ross 1995). However, the economic benefits of foreign capital are mostly concentrated among a small fraction of the local population so poverty remains pervasive (Evans 1979). This is especially true for women, who make up the majority of the workforce in the export sector (Abraham and Abraham 1988). As such, maternal mortality often remains high because women cannot access basic health services that are already expensive because of cuts to government subsidies (Sullivan 1983). Further, women that work in the export sector are often fired from their jobs if they become pregnant, which plunges them deeper into poverty (McMichael 2004).

We are only aware of one cross-national study that examines whether or not structural adjustment increases maternal mortality. Buchman (1996) finds no support for this dependency theory hypothesis. This is somewhat surprising because other cross-national research demonstrates the deleterious effects of structural adjustment on other types of mortality. For example, Shandra, et al. (2003) observe that structural adjustment is associated with increased infant mortality. Bradshaw et al. (1993) find that it is associated with higher levels of child mortality. Thus, we seek to reevaluate the relationship between debt service, structural adjustment, and maternal mortality using data for the most recent period for a larger number of nations than previously examined.

\section{WORLD POLITY THEORY: HEALTH AND WOMEN'S NON-GOVERNMENTAL ORGANIZATIONS}

The preceding discussion suggests one way structural adjustment increases maternal mortality involves "weakening" the government (Rich 1994). As government services are cut, world polity theory argues that non-governmental organizations are increasingly playing an important role in 
meeting health needs in poor nations (Inonue and Drori 2006; Boli and Thomas 1999). This can occur in several different ways.

First, international non-governmental organizations provide financial and technical support for health services at the sub-national level (Smith 1995). In doing so, they seek to increase access to healthcare by building clinics, training staff, and organizing treatment campaigns. They also provide essential drugs to poor nations (e.g., antibiotics). For example, Save the Children funds community-based health programs in forty nations. The programs provide women with immunizations, prenatal care, postnatal care, and screening for high risk pregnancies-all factors that have the potential to reduce maternal mortality (Otchere and Ransom 2006). They also provide women with educational material about micronutrient supplements, birth spacing, and family planning. Further, Save the Children ensures clinics have appropriate obstetric equipment (e.g., blood pressure gauges, weighing scales, delivery kits, delivery beds, autoclaves, examination lamps, and incubators) (Orcherre and Ransom 2006).

The effectiveness of such programs in decreasing maternal mortality has been documented in poor nations (Baqui et al. 2008; Mercer et al. 2006; Mercer et al. 2004). For example, Mercer et al. (2006) find that maternal mortality declined in areas of Bangladesh where health non-governmental organizations were operating. The authors attribute this decline to health non-governmental organizations helping to establish a stable primary health care system. Their programs include providing health education pertaining to contraception and the importance of aseptic delivery (Mercer et al. 2004). These non-governmental organizations also employ "family health visitors," who visit an allocated number of households every 1-2 months. Such visitors are responsible for basic health and family planning counseling, delivery of contraception, delivery of micro-nutrients, and mobilization of women to use satellite clinics and other permanent healthcare facilities. The non-governmental organizations also recruit and train medical personnel to staff the satellite clinics, which provide basic curative services, antenatal care, and postnatal care (Mercer et al. 2004).

Second, international non-governmental organizations propagate cultural norms and standards (Boli and Thomas 1999). This usually involves disseminating information, setting standards, and writing codes of conduct. For instance, the International Confederation of Midwives and International Council of Nurses works with the World Health Organization to improve technical skills and leadership capacities of midwives and nurses (World Health Organization 2002). Accordingly, these groups brought together midwives and nurses to identify ways to improve educational materials for health professionals. The effort was to develop training materials that improve maternal healthcare services in poor nations. As a result, six manuals were published based on the input from the participants. In fact, the manuals are considered "best sellers" among World Health Organization publications (World Health Organization 2002). The manuals remain in high demand and have been recommended as basic texts for training not just midwives but other health professionals requiring obstetric skills.

Third, international non-governmental organizations help to shape the language of international agreements on health related matters. For example, health non-governmental organizations have been involved in the negotiation of treaties dealing with landmines, environment, breast milk substitutes, tobacco, and public health standards (Boli and Thomas 1999). In the absence of resources and formal mechanisms of enforcement, they monitor compliance by governments with the treaties (Frank 1999). Consequently, international nongovernmental organizations are in a position of pointing out embarrassing failures and 
hypocrisies of nations, which puts pressure on governments to adapt their behaviors to international norms (Hafner-Burton and Tsutsui 2005). It is also an ideal occasion for nongovernmental organizations to criticize the "parochial" views of assembled government leaders and contrast those views with their own ideas on global health problems (Bryant and Bailey 1997). A large non-governmental organization presence at international conferences reminds the public that alternative views exist on health issues than those put forth by governments and business leaders (Keck and Sikkink 1998).

The preceding discussion suggests that nations with high levels of health nongovernmental organizations should be associated less maternal mortality. While we test this line of reasoning below, a nuanced variation of this should be considered. Shen and Williamson (1999) suggest various factors related to women's status tend to decrease maternal mortality. For example, educated women were more likely than uneducated women to seek prenatal care and, thus, be at lowest rick for maternal mortality (Boerma 1987). Moreover, educated women have greater access to information about nutrition, birth spacing, and immunizations as well (Buchman 1996). Further, women with higher levels of education also delay the age of first marriage, which decreases the childbearing years and the risks associated with giving birth before becoming fully developed physically (Buckingham-Hatfield 2000). Finally, many maternal deaths occur because women have more pregnancies than they want (Royston and Armstrong 1989). If women who do not want to become pregnant are empowered to exercise that choice, fewer women would die of pregnancy related causes (Royston and Armstrong 1989). One key source of empowerment may well come from the efforts of women's non-governmental organizations.

The projects and programs of many women's non-governmental organizations address health issues. Thus, women's non-governmental organizations should also help reduce maternal mortality. Like health non-governmental organizations, women's non-governmental organizations provide financial, technical, and organizational support to local populations. For example, the African Women's Development Fund finances community-based health programs with a special emphasis on women's issues. They also provide health professionals with obstetric training (African Women's Development Fund 2005). Moreover, CARE operates health programs with an explicit focus on women, infants, and children. The programs include training local volunteers to be counselors, mentors, and monitors of community health. The volunteers help detect infants, children, and pregnant women suffering from illness (e.g., malaria, acute respiratory infections, diarrhea, and vitamin deficiencies) earlier when diseases are more easily treated (CARE 2007). CARE also trains birth attendants, makes safe delivery kits available, promotes prenatal and postnatal care, provides information about birth planning, and transports women to health clinics for delivery. Currently, CARE operates fifty projects with a focus on mothers and children that have reached 9.5 million children in thirty-one poor nations (CARE 2007).

It is important to note that women's non-governmental organizations also conduct research and disseminate findings. The International Gender and Trade Network provides technical information on gender issues regarding human rights, health, intellectual property, trade, and agriculture. One report concerns the harmful impact of debt and structural adjustment on women (Williams 2007). This information has been used by women's non-governmental organizations, including the Women's Environment and Development Organization, to lobby for changes at the World Bank and International Monetary Fund. Further, the Association for Women's Rights in Development employs frames and discourses around issues like this to 


\section{DEBT, NGOS, AND MORTALITY 224}

encourage social movement activity within a nation (Keck and Sikkink 1998). As such, governments, corporations, and multilateral lending institutions are often "squeezed" from above by international non-governmental organizations and below by domestic social movements to attend to health issues (Schofer and Hironaka 2005).

Of course, women's non-governmental organizations implement programs and projects that deal with issues other than health (e.g., education, economics, etc.), which have the potential to reduce maternal mortality (Shen and Williamson 1999). For example, the Women's Empowerment Literacy and Development Organization has implemented the "Actions for Gender Responsive Economic Development” program that is aimed at improving educational and economic opportunities for women in Pakistan (Williams 2007). It does so by providing women with access to high quality secondary education opportunities especially in rural areas. It also provides participants with tuition scholarships to attend particular universities. This program not only seeks to increase access to education for women but also builds their capacity in resume preparation, interview preparation, and confidence building. The Women's Empowerment Literacy and Development Organization also operates a micro-finance program, which provides loans for women to start small businesses (Williams 2007).

Such programs may translate into less maternal mortality in poor nations for a few reasons. First, women, who have been educated and have more economic opportunities, are likely to marry later, delay childbearing, and have smaller and healthier families (United Nations 1995). Second, educated women and those with financial resources can recognize the importance of health care, know how to seek it for themselves and their children, and have the means to pay for such care (Shen and Williamson 2001). Third, educated and employed women also have greater influence in household negotiations, and this allows them to secure more resources for infants and children (United Nations 1995). Fourth, education helps women know their rights and gain confidence to claim them (Shen and Williamson 1999). Consequently, women may become empowered to exercise the choices regarding if or when to become pregnant, leading to a lower risk of dying from pregnancy related causes (Royston and Armstrong 1989). Finally, programs, like the ones described above, have the potential to raise the level of economic development in a nation by training women for jobs and mobilizing resources for economic growth that might otherwise not be available (Bradshaw and Schafer 2000). Higher levels of economic development are often associated with advanced medical technology and demographic changes that tend to lower mortality as well (Bradshaw and Schafer 2000).

The theoretical and anecdotal evidence suggests health and women's non-governmental organizations should improve well being in poor nations. In fact, cross-national research has examined the impact of non-governmental organizations on a variety of topics. For instance, Shandra (2007) finds that higher levels of environmental non-governmental organizations are associated with less deforestation. Schofer and Hironaka (2005) find that higher levels of environmental non-governmental organizations are correlated with lower levels of carbon dioxide emissions. Bradshaw and Schafer (2000) find a beneficial impact of international nongovernmental organizations on overurbanization, economic growth, and access to clean drinking water. Frank, Hironaka, and Schofer (1999) find that environmental non-governmental organizations tend to increase the amount of protected land area. Schafer (1999) finds international non-governmental organizations are associated with increases in various measures of educational attainment. However, world polity insights have not yet been applied to a crossnational study of maternal mortality. We begin to address this gap in the literature by conducting 
the first cross-national study to examine the impact of both health and women's nongovernmental organizations on maternal mortality.

It is also important to note that we consider insights for other theoretical perspectives in our models. As such, we include several other variables that have previously been including in analyses of maternal mortality. They are gross domestic product per capita, economic growth, education, female education, public health expenditures, democracy, skilled health attendants, domestic investment, total exports, and multinational corporate investment. We provide a brief rationale for their inclusion below. However, we now turn to a discussion of our modeling strategy.

\section{METHODOLOGY}

We use lagged dependent panel regression analysis to account for change in maternal mortality. In this sort of analysis, the dependent variable at a recent point in time is regressed on itself and other independent variables at an earlier point in time. This design is represented in the following mathematical notations:

$$
Y_{t}=B_{0} Y_{t-1}+B_{1}+B_{2} X_{t-1}+E_{t}
$$

The dependent variable $\left(Y_{t}\right)$ is hypothesized to be determined by the lagged dependent variable $\left(Y_{t-1}\right)$, the constant $\left(B_{1}\right)$, the lagged value of the independent variable $\left(X_{t-1}\right)$, and an error term $\left(E_{t}\right)$.

Ideally, we would prefer to use a full difference model or a more sophisticated longitudinal research design (e.g., fixed-effects or random effects model)—see Brady, Kaya, and Beckfield (2007) for an in depth explanation and application of these methods. However, we are limited to the lagged dependent panel design due to data availability. In particular, we only have data at one time point (i.e., 1990) for two key independent variables-health and women's nongovernmental organizations. Nevertheless, a lagged dependent variable model does have a couple of advantages over a cross-sectional research design. First, our approach helps rule out reciprocal effects and reduces threats of spuriousness, that is, the possibility that some other variable causes both the dependent and independent variables by including a lagged version of the dependent variable (Finkel 1995). Second, given the usually high correlation between the dependent variable at the two points in time in the model, this method yields very conservative estimates of the effect of the independent variables (Finkel 1995). Thus, the lagged panel design is viewed as a powerful tool for making causal inferences with non-experimental data (Allison 1990).

Of course, there are some potential limitations that should be addressed when using lagged dependent variable panel regression. First, it is possible that including a lagged variable may introduce serial correlation of errors or autocorrelation (Finkel 1995). However, this would produce a more conservative test of hypotheses because the effect of the lagged dependent variable is inflated relative to the estimated effects of the independent variables (London 1988). Nevertheless, we calculate Durbin-Watson statistics for each model. The results indicate no potential problems with autocorrelation. Second, heteroskedasticity may be problematic if the distributions of the dependent and lagged dependent variables are skewed (London and Ross 1995). Therefore, we transform the dependent and lagged dependent variables using the natural logarithm. We also compute Breusch-Pagan tests to determine if heteroskedasticity is 
problematic (Menard 2002). The results of these tests indicate no potential problems with heteroskedasticity.

\section{Sample}

We include nations that are not classified as "high" income according to the World Bank's (2003) income quartile classification scheme. ${ }^{2}$ We also do not include nations formed following the collapse of the Soviet Union because there are no data for these nations in 1990. We exclude high income nations because they are not the recipients of structural adjustment loans and do not have debt service obligations to the International Monetary Fund and World Bank. This yields a sample of sixty-five nations for which complete data are available. We follow the standard practice of checking for influential cases and outliers. There do not appear to be any potential problems with influential cases or outliers.

\section{Dependent Variable}

\section{Maternal Mortality Ratio:}

The dependent variable for this analysis is the maternal mortality ratio. The data may be obtained from the World Health Organization (2006). They are available for 2000. The maternal mortality ratio is the annual number of deaths of women from pregnancy-related causes, when pregnant or within 42 days of termination of pregnancy, per 100,000 live births (World Health Organization 2006). It is a measure of the risk of death to a woman from pregnancy, abortion, delivery, and problems encountered in the postpartum period (Boerma 1987; McCarthy and Maine1992). The lagged dependent variable is the maternal mortality ratio for 1990. Again, we log both variables to deal with potential heteroskedasticity problems. It is important to note that reliable estimates of maternal mortality are difficult to obtain because of widespread underreporting and misclassification (Rice 2008). Consequently, we use the adjusted maternal mortality data, which helps take into account these issues.

\section{Independent Variables}

\section{Health Non-Governmental Organizations:}

This is the first cross-national study to consider the impact of health non-governmental organizations on maternal mortality. We obtained the data from Inonue and Drori (2006). Like other world polity scholars (Shandra 2007; Schofer and Hironaka 2005; Boli and Thomas 1999; Frank 1999), Inonue and Drori (2006) rely on the most tangible and quantifiable source of information to gather these data, The Yearbook of International Organizations published by the

\footnotetext{
${ }^{2}$ There are seventy nations used in the analysis. They include Albania, Algeria, Angola, Argentina, Bangladesh, Benin, Bolivia, Botswana, Brazil, Bulgaria, Burundi, Cameroon, Central African Republic, Chad, Chile, Columbia, Congo, Costa Rica, Ecuador, Egypt, El Salvador, Ethiopia, Gambia, Ghana, Guinea, Guinea Bissau, Honduras, Hungary, Indonesia, Iran, Jamaica, Kenya, Lesotho, Madagascar, Malawi, Malaysia, Mali, Mauritius, Mexico, Mauritania, Morocco, Mozambique, Niger, Nigeria, Pakistan, Paraguay, Peru, Poland, Romania, Rwanda, Senegal, Sierra Leone, Sri Lanka, Swaziland, Syria, Tanzania, Thailand, Togo, Tunisia, Turkey, Uganda, Uruguay, Venezuela, Yemen, and Zambia.
} 
Union of International Associations. This publication collects information on international organizations (e.g., location, history, goals, activities, finances, and structures) and classifies them by subject (e.g., health, human rights, science, environment, etc.). Inonue and Drori (2006) collected data on counts of international non-governmental organizations within a nation that are classified by the Union of International Associations under the "health" category. According to the Yearbook of International Associations, an international non-governmental organization is a non-governmental organization that has operations or members in two or more nations - see below for a discussion of the limitations of using this operationalization. The data are measured in 1990. We divide the count for each nation by the country's 1990 population size in millions from the World Bank in order to standardize the measure. We log this variable to correct for its skewed distribution. From above, we hypothesize that higher levels of health non-governmental organizations should be associated with lower levels of maternal mortality.

One potential limitation of the data is that they include only international nongovernmental organizations. Domestic non-governmental organizations are excluded from the totals for each nation. This clearly underestimates the number of non-governmental organizations working on health issues within a nation. As Bradshaw and Schafer (2000) note, however, data on domestic non-governmental organizations are not widely available because domestic nongovernmental organizations are often very small and, therefore, not registered with the government or other international bodies (e.g., World Health Organization). Further, some domestic non-governmental organizations may try to "disguise" their efforts from the government to avoid interference or harassment (Bradshaw and Schafer 2000).

Another potential data limitation pertains to the variable measuring the number of health non-governmental organizations per capita within a nation. This tells us nothing about the types of projects being undertaken or the amount of money being spent on health projects that may reduce maternal mortality. While this type of detailed data would provide a more accurate test of the relationship between health non-governmental organizations and maternal mortality, we are not aware of such data being available at this time for a large number of nations. However, if they become available, then future research would benefit greatly from their use.

\section{Women's Non-Governmental Organizations:}

We also include number of women's non-governmental organizations per capita for each nation. These data were collected by Woptika and Ramirez (2007), who collected the data for their study dealing with ratification of the United Nations Convention on the Elimination of All Forms of Discrimination Against Women. These data also come from The Yearbook of International Associations. Woptika and Ramirez (2007) collect the counts of all international nongovernmental organizations within a nation that are classified in the "women" subject category by the Union of International Associations. We divide the counts for each nation by a nation's total population to standardize it for comparison across nations. We also log this variable to deal with its skewed distribution. This measure shares the same limitations as the health non-governmental organization variable. Like health non-governmental organizations, world polity theory hypothesizes that high levels of women's non-governmental organizations should be associated with less maternal mortality. 
Structural Adjustment:

To capture the effects of structural adjustment, pressure, and conditionality required by the International Monetary Fund and other multilateral lenders, Walton and Ragin (1990) developed a conditionality index. It has been used previously by Shandra, London, and Williamson (2003), Bradshaw and Schafer (2000), Schafer (1999), and Buchman (1996). This index is the sum of four variables which include (1) the number of debt renegotiations between a country and an international financial body, (2) the number of debt restructurings experienced by an indebted nation, (3) the number of times a country utilized the International Monetary Fund Extended Fund Facility, and (4) the total International Monetary Fund loans received by a country as a percentage of its allocated quota. The variables are measured in 1990. The four components of the index are converted to z-scores and summed. The index effectively approximates structural adjustment because the International Monetary Fund imposes conditions in each of its negotiations and renegotiations with indebted nations (Walton and Ragin 1990). See Walton and Ragin (1990) for a more detailed discussion. We hypothesize that structural adjustment should be correlated with increased maternal mortality.

Total Debt Service Ratio:

In addition to the pressure to adjust their economies under structural adjustment, indebted nations must continually service their foreign debts. Therefore, it is also important to control for debt service as well as structural adjustment. This approach has been used previously by Bradshaw and Schafer (2000), Schafer (1999), and Buchman (1996). Thus, we also include the average sum of principal and interest payments in foreign currency, goods, or services on long-term public and publicly guaranteed private debt with maturity of one year or longer as a percentage of goods and services exports in 1990. As mentioned earlier, we expect total debt service should be associated with more maternal mortality.

International Monetary Fund and World Bank Debt Service Ratio:

As suggested by dependency theory, we also include the average debt service ratio that covers long-term public debt and repayments only to the International Monetary Fund and World Bank. The data are measured as a percentage of exports of goods and services for 1990. Like total debt service, this variable should also be associated with higher maternal mortality.

\section{Multinational Corporate Investment:}

We also include multinational corporate investment as a percentage of gross domestic product per capita for 1990 in the models. This is an important variable to control for because structural adjustment often recommends that poor nations boost foreign investment in order to receive a loan. These data may be obtained from the United Nations (2003). We log this variable to correct for its skewed distribution. According to dependency theory, multinational corporate investment should be associated with increased maternal mortality (Jorgenson, Dick, and Mahutga 2007).

Total Exports:

We also include total exports as a percentage of gross domestic product in the models. We do so in order to determine the effects of debt service and structural adjustment independent of the trade 


\section{JOURNAL OF WORLD-SYSTEMS RESEARCH}

structure of a nation (Jorgenson 2003). The variable is measured in 1990. Dependency theory posits that higher levels of exports should be associated with increase maternal mortality.

\section{Domestic Investment:}

We also include a measure of domestic investment as a percentage of gross domestic product for 1990. We log this variable to deal with its skewed distribution. It is standard to control for this variable when considering the impact of foreign investment (Jorgenson 2009). We hypothesize that domestic investment should be associated with decreased infant mortality because it increases revenue available for investment by governments via taxes for social services.

\section{Gross Domestic Product:}

As is standard in such analyses, it is incumbent on us to take into account a nation's level of development in order to make sure that any effects discovered are independent of a nation's level of wealth (London and Ross 1995). In this regard, we employ a measure of gross domestic product per capita at parity purchasing power for 1990. All data may be obtained from the World Bank (2003) except where noted. We log this variable to correct for its skewed distribution. Buchman (1996) finds that this variable decreases maternal mortality. This is because economic development tends to bring a higher standard of living, advanced medical technology, and demographic changes that tend to lower mortality (Rostow 1990). Rice (2008) and Bulato and Ross (2003) among many others find that gross domestic product per capita is associated with lower levels of maternal mortality. We expect to find a similar relationship.

\section{Economic Growth Rate:}

We also include the average annual economic growth rate from 1980 to 1990. It is generally thought that economic growth should be related to less maternal mortality because more capital is available for investment in health and other social services (Kelly and Cutright 1980). Shen and Williamson (1999) find support for this hypothesis.

\section{Gross Secondary School Enrollments:}

We also include gross secondary school enrollment to examine the impact of education on maternal mortality. The data are measured in 1990. It is generally thought that education results in higher earning in the wage labor market, thereby increasing economic growth (Shen and Williamson 1999). The economic growth augments standards of living and access to advanced medical technology. Shiffman (2000) finds that higher levels of secondary school enrollment are associated with lower levels of maternal mortality. Therefore, we expect to find a similar relationship here.

Female Secondary School Enrollments:

We use female secondary school enrollments as an alternative indicator of education. The data are available for 1990. We do so because female education may have a unique impact on maternal mortality. Also, many women's non-governmental organizations try to empower women through education, which may lead to less maternal mortality. From above, we hypothesize that female secondary school enrollment should decrease maternal mortality because it is associated with wider use of health services. It also improves access to information about nutrition, birth spacing, and immunizations. These factors all have the potential to decrease 
maternal mortality. Shiffman (2000), Shen and Williamson (1999), and Buchman (1996) find support for the hypothesis that female education is correlated with less maternal mortality.

Public Health Expenditures:

We measure the regulatory capacity of a nation by including public health expenditures as a percentage of gross national product in the models. The data are measured in 1990. This measure includes all current expenditures by all levels of government for the provision of medical services. Moon and Dixon (1985) argue that government spending is an important corrective for "negative" externalities generated by private market activity. Rice (2008) and Dyches and Rushing (1996) find support for this hypothesis in their cross-national studies of maternal mortality. Thus, we expect public health expenditures to decrease maternal mortality as governments invest in healthcare, education, and other social services.

\section{Democracy:}

We use the average of Freedom House's (1997) political rights and civil liberties scales to measure democracy. Political rights reflect the degree to which a nation is governed by democratically elected representatives and has fair, open, and inclusive elections. Civil liberties reflect whether within a nation there is freedom of press, freedom of assembly, general personal freedom, freedom of private organizations, and freedom of private property (Freedom House 1997). We recode the variables so they have the following seven-point scale: not free (1-2), partially free (3-5), and free (6-7). London and Williams (1990) find that higher levels of democracy are associated with increased basic needs provision measured by the Physical Quality of Life Index and Index of Net Social Progress. Midlarsky (1998) suggests that such a finding can be attributed to freely elected and open governments responding to popular demands for basic needs provision due to political activism and electoral accountability. Thus, we hypothesize that higher levels of democracy should be related to decreased maternal mortality.

\section{Skilled Attendants at Delivery:}

We also include the percentage of births with skilled attendants present. The data are measured for various years during the 1990s. The data may be obtained from the World Resources Institute (2007). We log this variable to correct for its skewed distribution. The most direct causes of maternal mortality include hemorrhage, infection, and obstructed labor (Royston and Armstrong 1989). The presence of a skilled attendant at birth has the potential to decrease the risk of death from these complications. In fact, Anand and Barnighausen (2004) and Cook (2002) find support for this contention. As such, we anticipate that this variable should be associated with less maternal mortality. 
231 JOURNAL OF WORLD-SYSTEMS RESEARCH

Table 1

Descriptive Statistics and Bivariate Correlation Matrix for Maternal Mortality Analysis (1990-2000) $(\mathrm{N}=65)$

\begin{tabular}{|c|c|c|c|c|c|c|c|c|c|c|c|c|c|c|c|c|c|c|}
\hline & Mean & $\underline{\text { Standard Deviation }}$ & (1) & (2) & (3) & (4) & (5) & (6) & (7) & (8) & (9) & (10) & (11) & $(12)$ & (13) & (14) & (15) & (16) \\
\hline (1) Maternal Mortality, 2000 & 5.599 & 1.330 & 1.000 & & & & & & & & & & & & & & & \\
\hline (2) Maternal Mortality, 1990 & 5.906 & 1.163 & .929 & 1.000 & & & & & & & & & & & & & & \\
\hline (3) Gross Domestic Product, 1990 & 7.651 & .820 & -.870 & -.844 & 1.000 & & & & & & & & & & & & & \\
\hline (4) Economic Growth Rate, 1980-1990 & 2.732 & 4.742 & -.075 & .020 & -.007 & 1.000 & & & & & & & & & & & & \\
\hline (5) Total Secondary Education, 1990 & 35.492 & 23.942 & -.857 & -.821 & .737 & -.089 & 1.000 & & & & & & & & & & & \\
\hline (6) Female Secondary Education, 1990 & 33.448 & 25.439 & -.889 & -.875 & .796 &. .083 & .969 & 1.000 & & & & & & & & & & \\
\hline (7) Democracy, 1990 & 3.577 & 1.635 & -.67 & -.598 & .650 & .166 & .457 & .528 & 1.000 & & & & & & & & & \\
\hline (8) Public Health Expenditures, 1990 & 2.112 & 1.230 & -245 & -.347 & .225 &. .331 & .152 & .204 & .232 & 1.000 & & & & & & & & \\
\hline (9) Skilled Attendants at Birth, 1990 & 65.571 & 27.987 & -.833 & -.834 & .853 & .029 & .722 & .780 & .557 & .283 & 1.000 & & & & & & & \\
\hline (10) Domestic Investment, 1990 & 2.929 & .346 & -.437 & -.413 & .350 & .273 & .299 & .335 & .239 & .039 & .449 & 1.000 & & & & & & \\
\hline (11) Health NGOs & 2.210 & 2.471 & -.300 & -.256 & .343 & .031 & .207 & .264 & .394 & .304 & .299 & .219 & 1.000 & & & & & \\
\hline (12) Women's NGOs & 3.53 & 5.128 & -.161 & -.059 & .216 & .210 & .094 & .127 & .388 & .151 & .193 & .212 & .848 & 1.000 & & & & \\
\hline (13) Structural Adjustment, 1990 & 1.886 & 4.481 & .017 & -.046 & -.002 & .007 & -.008 & .020 & .281 & .198 & .019 & -.115 & -.064 & -.003 & 1.000 & & & \\
\hline (14) Multinational Corporate Investment, 1990 & 1.789 & 1.278 & -.042 & -.065 & .172 & .041 & .025 & .095 & .106 & .041 & .241 & .215 & .278 & .321 & .102 & 1.00 & & \\
\hline (15) Total Exports, 1990 & 26.370 & 15.682 & -.357 & -.297 & .422 & .273 & .236 & .276 & .326 & .108 & .426 & .322 & .549 & .617 & -.034 & .502 & 1.000 & \\
\hline (16) Total Debt Service, 1990 & 21.909 & 13.362 & .074 & .021 & -.064 & .159 & -.109 & -.066 & .133 & .004 & -.086 & -.068 & -.116 & -.185 & .159 & -.145 & -.206 & 1.000 \\
\hline (17) IMF-WB Debt Service, 1990 & 20.386 & 13.036 & .065 & .029 & -.075 & .183 & -.097 & -.072 & .130 & -.019 & -.109 & -.053 & -.137 & -.179 & .147 & -.210 & -.200 & .966 \\
\hline
\end{tabular}




\section{FINDINGS}

In Table 2, we present the lagged dependent variable panel regression estimates of maternal mortality. ${ }^{3}$ We also report one-tailed tests of statistical significance because of the high correlation between the dependent and lagged dependent variables, which yields very conservative estimates of the effect to the independent variables (Finkel 1995). In every equation, we include the lagged dependent variable, gross domestic product per capita, economic growth, one measure of enrollments, public health expenditures, democracy, percentage of attendants at birth, domestic investment, one measure of non-governmental organizations, structural adjustment, a measure of debt service, multinational corporate investment, and total exports. We include gross secondary school enrollments in odd-numbered equations and female secondary school enrollments in even-numbered equations. In equations (2.1) through (2.4), we include total debt service. In equations (2.5) through (2.8), we include debt service only to the International Monetary Fund and World Bank. In equations (2.1), (2.2), (2.5), and (2.6), we include health non-governmental organizations. In the other equations, we examine the effect of women's non-governmental organizations on maternal mortality.

We organize our analysis in this way for several important reasons. First, we want to avoid potential problems with multicollinearity. When we include both measure of debt service in the analysis at the same time, for example, variance inflation factor scores are greater than ten. This is likely due to the high bivariate correlation between these variable $(r=.967)$. However, the highest variance inflation factor score are less than ten in models where we examine the effects of these variables separately. The same logic applies to examining health and women's non-governmental organizations in different equations. Second, the sequential use of "cognate" but "distinct" indicators of more than one independent variable should shed considerable light on the complexity of dynamics involving the issue under investigation (London and Ross 1995). If both the health and women's non-governmental organization indicators maintain similar effects on maternal mortality, for example, then confidence in the findings regarding their beneficial impact on health is enhanced. Third, multiple indicators help guard against potential problems associated with measurement error, because one indicator may be imperfect but several measures are less likely to have the same error (Paxton 2002).

Let us begin by considering our statistically significant findings. First, we find substantial support for dependency theory that both debt and structural adjustment are correlated with increased maternal mortality. The coefficients for structural adjustment are positive and significant in every equation. The coefficients for the two debt service ratios are also positive and significant in three of eight equations. Second, we find multination corporate investment is associated with increased maternal mortality. The coefficients for this variable are positive and significant in every equation of Table 2. Third, we find that the level of development is an important predictor of maternal mortality. The coefficients for gross domestic product per capita are negative and significant in every equation. Likewise, we also find that economic growth is an important determinant of maternal mortality. The coefficients for this variable are negative and

\footnotetext{
${ }^{3}$ We also estimate cross-sectional models by dropping the lagged dependent variable from the analysis. The results are similar to the findings presented in Tables 2 and 3. We do not report these results for sake of space, but they are available from the authors upon request.
} 
significant in all eight equations. Fourth, we observe that education is a significant predictor of maternal mortality. The coefficients for both total and female secondary school enrollments are negative and significant in every equation. ${ }^{4}$ Fifth, we find that higher levels of democracy are associated with decreased maternal mortality. The coefficients are also negative and significant in every equation of Table $2 .^{5}$

There are some other non-significant findings that also should be mentioned. First, we find no evidence that public health expenditures are related to decreased maternal mortality. The coefficients are not significant in any equation. ${ }^{6}$ Second, we also do not find support that domestic investment tends to be associated with less maternal mortality. This variable does not significantly predict the dependent variable. Third, there is no evidence that the presence of skilled health attendants at birth affects maternal mortality. The coefficients are also not statistically significant. ${ }^{7}$ Fourth, we find no support for the hypothesis that higher levels of health or women's non-governmental organizations are associated with less maternal mortality. The coefficients for both variables fail to achieve a level of statistical significance.

The failure of health and women's non-governmental organizations to significantly predict maternal mortality is somewhat surprising given the substantial amount of theoretical and case study evidence that suggests such a relationship should exist. Thus, it calls for additional comment. Wiktorowicz (2001), Lewis (2000), Payne (1995), Tarrow (1994), Bratton (1989), and Kitschelt (1986) among others suggest that governments may be able to enhance or restrict the effectiveness of non-governmental organizations since they provide the "political opportunity

\footnotetext{
${ }^{4}$ We also examined the effects of total literacy and female literacy on maternal mortality. The results regarding the key findings are similar to the ones presented. However, we lose fifteen nations to missing data. In order to preserve as many nations as possible, we do not present these results. They are available from the authors upon request.

${ }^{5}$ Bollen and Paxton (2000) argue that non-random measurement error arising from the subjective perceptions of judges affect all cross-national measures of democracy to some degree. This bias may distort comparisons across nations, undermining empirical results that ignore it. Therefore, we also estimate our models using the level of democracy or autocracy in a nation using data from the Polity IV Project (2005). This measure ranges from - 10 (autocracy) to 10 (democracy). The results using this measure are very similar to the results reported for the measurements of democracy in Table 1. We do not present these results for sake of space, but they are available upon request.

${ }^{6}$ We contribute the failure of public health spending to significantly predict maternal mortality in part to debt service and structural adjustment weakening the regulatory capacity of governments to deal with issues like this one. According to the World Bank (1991), however, measures of public health expenditures do not reveal how resources are allocated. Governments can fund elaborate curative care programs and expensive hospitals instead of primary healthcare (e.g., immunizations, prenatal care, and nutrition), which may not translate into improvements in maternal mortality. Thus, Buchman (1996) examines immunizations as a proxy for basic health services provided by the government. We obtained these data from the World Resources Institute (2007) and included them in our models. This variable failed to explain any significant variation in maternal mortality. We do not present the results, but they are available from the authors.

${ }^{7}$ Robinson and Wharrad (2001) find that the doctors per 1,000 people are associated with decreased maternal mortality. Therefore, we included this variable in the analysis rather than percentage of births attended by skilled health professionals. We did not find support for this hypothesis. The results are available upon request.
} 


\section{DEBT, NGOS, AND MORTALITY 234}

structure" in which non-governmental organizations operate. This point is fairly obvious in a repressive nation where non-governmental organizations are often tolerated only if they meet with the approval of government officials (Bryant and Bailey 1997). Some overt forms of oppression used include arresting protesters or assassinating protest leaders (Karliner 1997).

However, repressive nations also tend to use their law-making powers to "dull the sharp edge of non-governmental organization criticism" (Clark 1991: 179). Wiktorowicz (2002) refers to this process as "administrative repression" where legal codes and bureaucratic regulations are used to control non-governmental organizations. For example, the government of Jordan uses the Law of Societies and Social Organizations in such a way. The Law of Societies and Social Organizations requires non-governmental organizations to obtain a permit from the government in order to form. Once a permit is obtained, a non-governmental organization must submit to the government a detailed record of its activities in an annual report, which includes information on finances, correspondence, board meetings, fixed assets, revenues, and working members (Wiktorowicz 2002). The Jordanian government also has the right to perform inspections, issue violations, certify elections of executive committees, and reorganize leadership "to prevent activities deemed threatening to the regime” (Wiktorowicz 2002: 84).

Similar "administrative co-option" happens in other repressive nations (Fowler 1991). Bryant and Bailey (1997) note that Indonesia requires all non-governmental organizations working in the country to register members and seek approval of funding for any project. The law also permits the government to ban any non-governmental organization without explanation (Hurst 1990). Similar situations have been documented in nations including Zaire (Bryant and Bailey 1997), Tanzania (Tripp 2000), and China (Sullivan 1995). Clearly, repressive nations through overt and administrative repression may limit the effectiveness of health and women's non-governmental organizations to deliver health services.

Nevertheless, democracy may enhance the ability of non-governmental organizations to deal with the causes of maternal mortality (Payne 1995). In part, this may be the result of democratic nations providing citizens with political opportunity structures to engage in public policy debates. It usually includes protections of speech, press, and assembly (Tarrow 1994). It may also be due to democratic leaders being more likely to tolerate such activism in order to maintain legitimacy (Midlarsky 1998). The responsiveness of public officials is partially based on the need for them to win popular elections to maintain their positions (Midlarsky 1998). The officials who fail to address the needs of citizens or at least give the impression of concern face the risk of losing their position in subsequent elections (Lewis 2000). Thus, democracy may enhance the effectiveness of health and women's non-governmental organizations to provide services that are may lead to less maternal mortality.

We draw upon these ideas to test if health and women's non-governmental organizations are associated with less maternal mortality at higher levels of democracy than at lower levels of democracy. We do so by including interaction terms between democracy and each nongovernmental organization variable. We provide estimates of the effects of health or women's non-governmental organizations at high levels of democracy (e.g., democracy $=7$ ) and low levels of democracy (e.g., democracy $=1$ ) (Jaccard and Turrisi 2001). The results are presented in Table 3, which has the same organization as Table 2. However, we now include an interaction term for health non-governmental organization and democracy in equations (3.1), (3.2), (3.5), and (3.6). We include an interaction term for women's non-governmental organizations and democracy in equations (3.3), (3.4), (3.7), and (3.8). Let us again begin with a discussion of the 


\section{JOURNAL OF WORLD-SYSTEMS RESEARCH}

interaction terms to determine if we find support for our political opportunity structure hypothesis.

We find substantial support for the political opportunity structure hypothesis. First, the interaction terms between democracy and health non-governmental organizations are significant in equations (3.1), (3.2), (3.5), and (3.6). The calculations reveal that health non-governmental organizations tend to decrease maternal mortality more at higher rather than lower levels of democracy. In equation (3.1), for example, the effect of health non-governmental organizations in nations with high levels of democracy is equal to -.060. The effect of health non-governmental organizations in nations with low levels of democracy is equal to .084. A similar pattern emerges in the other equations. Second, the interaction terms between women's non-governmental organizations and democracy are significant in equations (3.3), (3.4), (3.7), and (3.8). The calculations involving this interaction term reveal that women's non-governmental organizations are associated with less maternal mortality at higher rather than lower levels of democracy as well. In equation (3.3), for instance, the effect of women's non-governmental organizations on maternal mortality in nations with high levels of democracy is equal to -.012. The effect in nations with low levels of democracy is equal to .060. A similar pattern emerges in equations (3.4), (3.7), and (3.8), which contain interaction terms between women's non-governmental organizations and democracy.

We also continue to find support for other hypotheses. First, we find that debt service, structural adjustment, and multinational corporate investment are associated with increased maternal mortality. Note especially that for these more fully specified models the coefficients for the debt service ratios are now positive and significant in seven of eight equations of Table 3. The coefficients for structural adjustment are positive and significant in four of eight equations in Table 3. The coefficients for multinational corporate investment are positive and significant in every equation. Second, we continue to find that gross domestic product per capita and economic growth are associated with less maternal mortality. The coefficients for these variables are negative and significant in every equation. Third, we find that both total and female secondary school enrollments are related to decreased maternal mortality. The coefficients for both educational variables remain negative and significant in every equation. The majority of findings remain stable and consistent. ${ }^{8}$

\footnotetext{
${ }^{8}$ In order to further increase the reliability of the findings, we also include dummy variables for the region of the world in which a nation is located. This allows us to deal with findings that may arise out of geographical circumstances, which cannot be accounted for by the independent variables in the model. These dummy variables identify a nation as being located in Latin America, Asia, Europe, and Africa. The reference category includes nations in Middle East. The coefficients for the geographical control variables failed to predict any significant variation in maternal mortality. We also include a dummy variable for just Sub-Saharan African nations due to the high levels of maternal mortality in just this region relative to the rest of the world. The coefficients for the Sub-Saharan dummy variable are positive but not statistically significant. Please note that the other findings remained similar to the results reported in Tables 2 and 3. We do not present the results for sake of space, but they are available from the authors upon request.
} 
DEBT, NGOS, AND MORTALITY 236

Table 2

Estimates of Maternal Mortality (1990-2005) Including Debt Service, Structural Adjustment, and Non-Governmental Organizations

Equation 2.1

Equation 2.2

Equation 2.3

Equation 2.4

Equation 2.5

Equation 2.6

Equation 2.7

Equation 2.8

National Variables:

Maternal Mortality Ratio,

1990

$.459^{\star \star \star}$
.402
$(.103)$

$-.241^{\star}$
-.149
$(.133)$
$-.021^{\star}$
-.075
$(.012)$

$-.016^{\star \star \star}$
-.287
$(.004)$

$\begin{array}{cc}.439^{\star \star \star} & .419^{\star \star \star} \\ .384 & .366 \\ (.112) & (.109) \\ & \\ -.229^{\star} & -.241^{\star} \\ -.141 & -.149 \\ (.137) & (.131) \\ & \\ -.021^{\star} & -.023^{\star} \\ -.076 & -.081 \\ (.012) & (.012) \\ & -.017^{\star \star \star} \\ & -.301 \\ & (.004)\end{array}$

$\begin{array}{cc}.397^{\star \star \star} & .455^{\star \star \star} \\ .347 & .398 \\ (.120) & (.103) \\ & \\ -.227^{\star} & -.242^{\star} \\ -.140 & -.149 \\ (.136) & (.133) \\ & \\ -.023^{\star} & -.021^{\star} \\ -.083 & -.075 \\ (.012) & (.012) \\ & -.016^{\star \star \star} \\ & -.291 \\ & (.004)\end{array}$

$\begin{array}{cc}.437^{\star \star \star} & .416^{\star \star \star} \\ .382 & .364 \\ (.113) & (.110) \\ & \\ -.230^{\star} & -.242^{\star} \\ -.142 & -.149 \\ (.138) & (.132) \\ -.021^{\star} & -.023^{\star} \\ -.074 & -.081 \\ (.012) & (.012) \\ & \\ & -.017^{\star \star \star} \\ & -.305 \\ & (.004)\end{array}$

Female Secondary School

$-.016^{\star \star *}$

$-.310$

$-.017^{\star \star \star *}$

$-.016^{\star \star \star}$

(.004)

Enrollments, 1990

(.004)

-.326
$(.004)$

-.312
$(.004)$

$-.017^{\star * \star}$

$-.327$

(.004)

Democracy,

$-.143^{\star \star *}$

$-.147^{\star \star *}$

$-.170^{\star \star * *}$

$-.161^{\star \star \star}$

$-.154^{\star * *}$

$-.146^{\star \star *}$

$-.169^{\star * *}$

$-.158^{\star \star \star}$

$-.197-.189$

(.043)

-.179
$(.044)$

$-.195$

(.045)

$-.021$

$-.022$

$-.015$

Public
1990

$-.022$

$-.018$

$-.030$

-.026
$(.051)$

$-.018$

(.053)

$-.014$

-.012
-0.05

(.045)

(.047)

$-.019$

$-.016$

Skilled Attendants at Delivery,

$-.002$

$-.038$

$(.053)$

(.052)

$-.030$

-.025
$(.045)$

$-.002$

$\begin{array}{ll}-.002 & -.002 \\ -.048 & -.039 \\ (.004) & (.004)\end{array}$

(.004)

$-.002$

-.038
$(.004)$

$-.002$

$-.033$

$-.002$

$-.036$

$-.002$

(.004)

$-.200$

$-.052$

$-.201$

$-.041$

(.157)

$-.195$

$-.051$

(.004)

$-.054$

$(.004)$

$-.050$

$-.048$

(.158)

$-.217$

$-.056$

$-.209$

$-.054$

(.163)

International Variables:

Health Non-Governmental

Organizations, 1990

$\begin{array}{cc}.013 & .017 \\ .024 & .033 \\ (.024) & (.025)\end{array}$

$\begin{array}{cc}.014 & .018 \\ .025 & .034 \\ (.024) & (.025)\end{array}$

Women's Non-Governmental

Organizations, 1990

Structural Adjustment,

1990

$.021^{*}$

.070

$.021^{\star}$

$$
\begin{gathered}
.071 \\
(.012)
\end{gathered}
$$

(.012)

Multinational Corporate Investment,

1990

$\begin{array}{lll}.069^{*} & .092^{*} & .069^{*}\end{array}$

.067

.088
$(.044)$

.066

$-.003 \quad-.003$

Total Exports,

1990

$-.002$

$-.024$

$-.033$

(.004)

$-.041$

(.004)

Total Debt Service Ratio,

1990

$.005 \quad .006^{*}$

.051

.065

.006

.058

(.004)

.016
.061

.061
$(.014)$

$.021^{\star}$
.071

(.012)

$.021^{*}$

(.011)

$.093^{*}$

.089

$.074 *$

.071

(.043)

$-.004$

$-.048$

$-.002$

$-.028$

(.043)

$.007^{*}$

.072

(.004)

International Monetary Fund-World

Bank Debt Service Ratio, 1990

Adjusted R-Square

Number of Cases

Highest Variance Inflation Factor Score

.931
65
5.990
2.516

.005

.006

.005

.054

$.006^{\star}$

(.004)

(.004)

(.004)

Notes:

a) * indicates $p<.05$, ** indicates $p<.01$, and ${ }^{* *} p<.001$ for a one-tailed test.

b) The first number reported is the unstandardized coefficient, the second number is the standardized coefficient, and the third number in parentheses is the standard error. 


\section{JOURNAL OF WORLD-SYSTEMS RESEARCH}

Table 3

Estimates of Maternal Mortality (1990-2005) Including Debt Service, Structural Adjustment, and Interaction Terms Between Non-Governmental Organizations and Democracy

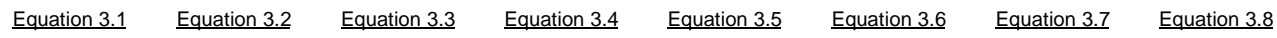

National Variables:

Maternal Mortality Ratio 1990

$\begin{array}{ccc}.455^{\star \star *} & .431^{\star * *} & .399^{\star \star \star} \\ .398 & .377 & .349 \\ (.099) & (3.987) & (.106) \\ & & \\ -.268^{*} & -.257^{\star} & -.286^{\star} \\ -.165 & -.158 & -.177 \\ (.129) & (.133) & (.128) \\ -.021^{\star} & -.022^{\star} & -.027^{\star} \\ -.076 & -.078 & -.096 \\ (.012) & (.012) & (.003) \\ & & \\ -.016^{\star * *} & & -.017^{\star * *} \\ -.285 & & -.313 \\ (.003) & & (.003)\end{array}$

$\begin{array}{cc}.370^{* * *} & .451^{\star * *} \\ .323 & .395 \\ (.116) & (.099) \\ -.273^{\star} & -.269^{*} \\ -.168 & -.166 \\ (.133) & (.129) \\ & \\ -.028^{\star *} & -.021^{\star} \\ -.099 & -.076) \\ (.012) & \\ & -.016^{\star * *} \\ & -.290 \\ & (.003)\end{array}$

\begin{tabular}{|c|c|c|}
\hline $.429^{\star \star \star}$ & $.396^{* \star *}$ & $.370^{\star \star \star \star}$ \\
\hline $\begin{array}{c}.375 \\
(.109)\end{array}$ & $\begin{array}{c}.346 \\
(.106)\end{array}$ & $\begin{array}{c}.324 \\
(.118)\end{array}$ \\
\hline$-.258^{*}$ & $-.287^{*}$ & $-.273^{*}$ \\
\hline-.159 & -.177 & - 169 \\
\hline (.134) & (.129) & (.134) \\
\hline$-.021^{*}$ & $-.027^{\star}$ & $-.027^{\star}$ \\
\hline \multirow{5}{*}{$\begin{array}{l}-.076 \\
(.012)\end{array}$} & -.095 & -.096 \\
\hline & $(.012)$ & $(.012)$ \\
\hline & $-.018^{\star \star \star}$ & \\
\hline & -.050 & \\
\hline & $(.003)$ & \\
\hline$-.016^{\star \star \star}$ & & $-.018^{* \star *}$ \\
\hline-.315 & & -.346 \\
\hline$(.004)$ & & $(.004)$ \\
\hline-.062 & $-.114^{\star}$ & $-.101^{*}$ \\
\hline-.076 & -.140 & -.124 \\
\hline$(.057)$ & (.050) & $(.052)$ \\
\hline .008 & -.032 & -.022 \\
\hline .007 & -.027 & -.019 \\
\hline (.155) & (.049) & $(.051)$ \\
\hline-.002 & -.001 & -.001 \\
\hline-.026 & -.025 & -.022 \\
\hline$(.004)$ & (.003) & $(.004)$ \\
\hline-.260 & -.226 & -.219 \\
\hline-.068 & -.059 & -.057 \\
\hline$(.160)$ & (.151) & $(.004)$ \\
\hline
\end{tabular}

\section{International Variables:}

Health Non-Governmental Organizations, 1990

$-.074^{\star * *}$
-.285
$(.051)$

.001
.001
$(.051)$
-.002
-.043
$(.003)$
-.253
-.066
$(.154)$

$-.016^{* \star *}$

-.016
-.312
$(.004)$

(.004)

$$
\begin{aligned}
& -.062 \\
& -.076 \\
& (.057)
\end{aligned}
$$$$
\text { (.057) }
$$

Public Health Expenditures, 1990

Skilled Attendants at Delivery, 1990

Domestic Investment,

Domestic
1990

Women's Non-Governmental

Organizations, 1990

Structural Adjustment,

1990

Multinational Corporate Investment,

1990

Total Exports,

1990

Total Debt Service Ratio

1990

International Monetary Fund-World

Bank Debt Service Ratio, 1990

Interaction Terms and Calculated Effects:

Corresponding Non-Governmenta

Organization Variable x Democracy

Calculated Effect at High Democracy

Calculated Effect at Low Democracy

Adjusted R-Square

Number of Cases

Highest Variance Inflation Factor Score

Mean Variance Inflation Factor Score

Notes:

a) * indicates $p<.05,{ }^{* *}$ indicates $p<.01$, and ${ }^{* * *} p<.001$ for a one-tailed test.

b) The first number reported is the unstandardized coefficient, the second number is the standardized coefficient, and the third number in parentheses is the standard error.

$\begin{array}{lllll}-.018^{\star \star *} & & -.016^{\star * *} & & -.018^{\star * \star} \\ -.345 & & -.315 & & -.346 \\ (.004) & & (.004) & & (.004) \\ & & & & \\ -.103^{\star} & -.074 & -.062 & -.114^{\star} & -.101^{*} \\ -.126 & -.091 & -.076 & -.140 & -.124 \\ (.052) & (.051) & (.057) & (.050) & (.052) \\ & & & & \\ -.025 & -.001 & .008 & -.032 & -.022 \\ -.021 & -.001 & .007 & -.027 & -.019 \\ (.051) & (.051) & (.155) & (.049) & (.051) \\ & & & & \\ -.001 & -.002 & -.002 & -.001 & -.001 \\ -.025 & -.040 & -.026 & -.025 & -.022 \\ (.051) & (.003) & (.004) & (.003) & (.004) \\ & & & & \\ -.208 & -.2622^{*} & -.260 & -.226 & -.219 \\ -.054 & -.068 & -.068 & -.059 & -.057 \\ (.156) & (.155) & (.160) & (.151) & (.004)\end{array}$

$\begin{array}{cc}.108^{*} & .119^{\star *} \\ .202 & .222 \\ (.049) & (.051)\end{array}$

$.072^{\star *}$
.277
$(.028)$

$.018^{*}$
.061
$(.011)$

$.067^{*}$
.064
$(.037)$

-.003
-.064
$(.003)$
$.007^{*}$
.065
$(.004)$

$\begin{array}{cc} & \\ & \\ & \\ .015 & .014 \\ .059 & .049 \\ (.011) & (.012) \\ & \\ .075^{\star} & .098^{\star *} \\ .072 & .094 \\ (.041) & (.042) \\ & \\ -.002 & -.002 \\ -.018 & -.027 \\ (.004) & (.004) \\ & \\ .006^{\star} & .007^{\star} \\ .059 & .073 \\ (.004) & (.004)\end{array}$

$.071^{\text {** }}$$$
\text { (.030) }
$$

$.018^{*}$

$$
\begin{gathered}
.060 \\
(.011)
\end{gathered}
$$

.015

.015
.050
$(.011)$

$.092^{*}$

$$
\begin{gathered}
.088 \\
(.042)
\end{gathered}
$$

$-.004$

-.004
-.047
$(.004)$

(.004)

\begin{tabular}{|c|c|c|c|c|c|c|c|}
\hline$-.024^{*}$ & $-.025^{\star}$ & $-.012^{*}$ & $-.012^{\star *}$ & $-.024^{\star}$ & $-.025^{\star \star}$ & $-.012^{*}$ & $-.012^{*}$ \\
\hline $\begin{array}{l}-.244 \\
(.011)\end{array}$ & $\begin{array}{l}-.258 \\
.011)\end{array}$ & $\begin{array}{l}-.255 \\
(.005)\end{array}$ & $\begin{array}{l}-.265 \\
(.005)\end{array}$ & $\begin{array}{l}-.243 \\
(.011)\end{array}$ & $\begin{array}{c}-.257 \\
(.011)\end{array}$ & $\begin{array}{c}-.252 \\
(.005)\end{array}$ & $\begin{array}{l}-.260 \\
(.005)\end{array}$ \\
\hline-.060 & -.056 & -.012 & -.013 & -.059 & -.055 & -.013 & .010 \\
\hline .084 & .094 & .060 & .059 & .085 & .095 & .059 & .062 \\
\hline .934 & .930 & .936 & .932 & .934 & .929 & .933 & .934 \\
\hline .65 & 65 & .65 & 65 & 65 & 65 & 65 & 65 \\
\hline 6.003 & 6.299 & 6.099 & 6.992 & 5.907 & 6.286 & 5.975 & 6.833 \\
\hline 2.552 & 2.714 & 2.548 & 2.793 & 2.505 & 2.679 & 2.500 & 2.782 \\
\hline
\end{tabular}

$.008^{*}$

.080
$(.004)$

$\begin{array}{cccc}.006 & .007^{*} & .005^{*} & .007^{*} \\ .056 & .066 & .061 & .071 \\ (.004) & (.004) & (.004) & (.004)\end{array}$

$\begin{array}{ccc} & .071^{\star *} & .074^{\star *} \\ & .274 & .284 \\ & (.029) & (.030) \\ & & \\ .015 & .018^{*} & .019^{*} \\ .049 & .061 & .060 \\ (.012) & (.011) & (.011) \\ & & \\ .103^{\star *} & .073^{*} & .099^{\star *} \\ .100 & .070 & .095 \\ (.043) & (.041) & (.043) \\ & & \\ -.003 & -.004 & -.004 \\ -.034 & -.044 & -.053 \\ (.004) & (.004) & (.004) \\ & & \end{array}$


DEBT, NGOS, AND MORTALITY 238

\section{DISCUSSION AND CONCLUSION}

We began this research with the goal of reevaluating dependency theory claims regarding how debt service and structural adjustment impact maternal mortality. We find substantial support for this theoretical perspective because both factors are associated with increased maternal mortality. The coefficients for the debt service variables are positive and significant in every equation. The coefficients for structural adjustment are also positive and significant every equation of Table 2 and half the equations of Table 3. A potential reason for these findings involves debt service and structural adjustment reducing the ability of governments to provide health, education, and other social services (Rich 1994). This line of reasoning may be supported to some extent by the nonsignificant coefficients for the public health expenditure variable throughout Tables 2 and 3. It may also well be that structural adjustment requires poor nations to liberalize trade by attracting foreign investment. In this regard, the coefficients for the multinational corporate investment variable are positive and significant.

We also extend previous cross-national research on health in a novel way. We conduct the first cross-nation study that empirically assesses world polity hypotheses that health and women's non-governmental organizations may be associated with less maternal mortality. Initially, we find no support for this hypothesis. The coefficients for the health and women's non-governmental organization variables are not statistically significant in Table 2. However we refine the analysis and test a political opportunity structure hypothesis, which suggests democracy enhances the ability of non-governmental organizations to deliver health, education, and other social services. We find substantial support for this line of reasoning in Table 3. The interaction terms between democracy and the both of non-governmental organization variables are statistically significant in every equation. The calculations involving the interaction terms reveal that health and women's non-governmental organizations are associated with decreased maternal mortality at higher levels rather than lower levels of democracy. We increase the reliability of the findings by demonstrating their significance across several alternative models specifications.

There are some important theoretical and methodological implications that correspond with the main findings. First, the results are reminiscent of an approach used by Shandra, Shandra, and London (2008). These authors find higher levels of environmental and women's non-governmental organizations are associated with lower rates of deforestation. Shandra, Shandra, and London (2008) conclude that it is necessary to consider both types of international non-governmental organizations in cross-national research on the environment. We extend this line of reasoning here but in a slightly different way. We demonstrate the importance of examining how health and women's non-governmental organizations impact maternal mortality. Such an approach provides us with a more detailed and nuanced understanding of the factors that shape this health outcome. At the same time, it allows us to suggest more accurate policy prescriptions to help deal with the causes of forest loss.

Some policy implications originate from our main findings too. First, it may serve health and women's non-governmental organizations well to continue to focus their efforts on projects that provide women with information about nutrition, birth spacing, reproductive rights, and immunizations. All of these factors have been shown previously to be associated with less maternal mortality (Shen and Williamson 1999). Second, these non-governmental organizations also should push governments to promote more democratic laws and regulations. These can include access to information, participation in decision making, transparency in government, and 
free and fair elections among many others. In fact, Annis (1987) argues a "virtuous circle" will emerge that strengthens the impact of both democracy and non-governmental organizations on development outcomes in poor nations. Maternal mortality may well be one such outcome. Third, health and women's non-governmental organizations could also focus on projects that seek to decrease debt and maternal mortality simultaneously. A "debt-for-development" swap is a very good example of this approach. The procedure usually entails non-governmental organizations paying off a portion of a nation's debt in return for that nation using the money generated from the swap to implement healthcare, education, and other basic needs programs (Bryant and Bailey 1997).

Nevertheless, debt-for-development swaps can be criticized for being "reformist" because the swaps do not address the causes of increasing debt among poor nations (e.g., structural adjustment) (Newell 2000). Bryant and Bailey (1997) write, "If the argument is that fundamental change is the only way in which to solve the debt crisis," then international non-governmental organizations "may be part of the problem and not part of the solution" (143). Accordingly, health and women's non-governmental organizations should also focus their efforts of lobbying leaders of lending institutions to abandon economic aid packages (i.e., structural adjustment) that are harmful to women, children, and infants and push for more substantial debt forgiveness. This process should also involve lobbying leaders in rich nations to withhold funding to the International Monetary Fund and World Bank until such changes occur (Rich 1994).

These policy suggestions also point to some promising avenues for future research. First, there has been no systematic cross-national research that examines the impact of debt-fordevelopment swaps on health issues. Thus, social scientists should consider if such swaps are related to reductions in maternal, infant, and child mortality. Second, the International Monetary Fund and World Bank's Enhanced Highly Indebted Poor Countries (HIPC) Initiative offers debt forgiveness and low interest loans to reduce debt repayments to "sustainable" levels. However, governments must meet a range of economic management and performance targets to qualify for the aid (Peet 2003). The HIPC Initiative targets usually involve liberalization of trade and fiscal policy (e.g., tax holidays, firing workers at will, and weakening of government regulations), which are quite similar to structural adjustment conditionality (Rich 1994). Thus, future research may also consider if debt relief provided under the HIPC Initiative tends to improve health (e.g., maternal mortality) or if the economic targets that must be met to qualify for the program undermine it. Third, we use cross-national data for a ten year period (i.e., 1990-2000) in order to examine how debt and structural adjustment impact maternal mortality. Unfortunately, comparable data on maternal mortality are limited to this time frame due to changes in data collection methodologies (World Health Organization 2005). We also only have data on health and women's non-governmental organizations for 1990. However, it may well be that macrostructural changes occur over longer periods of time and vary by region (Smith 1996). Our effort to gauge processes from the most recent period are bound to miss long-term trends and geographical differences. Clearly, we need more data for more nations and for time points. This would enable social scientists to use more sophisticated longitudinal modeling strategies (fixed effects or random effects models) than the methodology employed here-see Brady, Kaya, and Beckfield (2007) for a good discussion and illustration of these techniques. Further, crossnational research of this sort would be greatly aided by historical-comparative case study analyses (Smith 1996). The use of more complex longitudinal regression models and historical- 
comparative analyses would allow researchers to better determine how the patterns of findings presented here vary across time and space.

\section{ACKNOWLEDGEMENTS}

We would like to thank Gili S. Driori and Keiko Inoue for sharing their data on health nongovernmental organizations with us. Thanks also to Christine Min Woptika and Francisco O. Ramirez for allowing us to use their women's non-governmental organization data. Without their generosity, this paper would not have been possible. Thanks also to the editors and anonymous reviewers at JWSR for their insightful comments.

\section{REFERENCES}

Abraham, M. Francis and P. Subharda Abraham. 1988. Women, Development and, Change: The Third World Experience. Bristol: Wyndham Hall Press.

Allison, Paul. 1999. Multiple Regression: A Primer. Thousand Oaks: Sage.

Amin, Samir. 1976. Unequal Development: An Essay on the Social Formation of Peripheral Capitalism. New York: Monthly Review Press.

Annis, Sheldon. 1987. "The Next World Bank: Financing Development from the Bottom Up.” Grassroots Development 11: 24-29.

Arbuckle, James L. 1996. Amos users' guide. Chicago: Small Waters Corporation.

Anand, Sudhir and Till Barnighausen. 2004. "Human Resources and Health Outcomes: A CrossCountry Econometric Study.” The Lancet 364: 1603-1609.

Baqui, A. H., A. M. Rosecrans, E. K. Williams, P. K. Agarwal, S. Ahmed, G. L Darmstadt, V. Kumar1, U. Kiran, D. Panwar, R. C. Ahuja, V. K. Srivastava, R. E. Black, and M. Santosham. 2008. "NGO Facilitation of a Government Community-Based Maternal and Neo-Natal Health Program in Rural India: Improvements in Equity." Health Policy and Planning 23: 234-243.

Barbosa, Luiz C. 2001. The Brazilian Amazon Rainforest: Global Ecopolitics, Development, and Democracy. New York: University of American Press.

Bhagwati, Jagdish N. 2004. In Defense of Globalization. New York: Oxford University Press.

Boerma, Ties. 1987. "The Magnitude of the Maternal Mortality Problem in Sub-Saharan Africa." Social Forces 24: 551-558.

Boli, John and George. M. Thomas. 1999. Constructing World Culture: International NonGovernmental Organizations Since 1875. Stanford: Stanford University Press.

Bollen, Kenneth and Pamela. Paxton. 2000. "Subjective Measures of Liberal Democracy." Comparative Political Studies 33: 58-87.

Bornschier Volker and Christopher. Chase-Dunn. 1985. Transnational Corporations and Underdevelopment. Praeger: New York.

Bradshaw, York W. and Mark. Schafer. 2000. "Urbanization and Development: The Emergence of International Non-Governmental Organizations among Declining States.” Sociological Perspectives 43: 97-116. 
Bradshaw, York W., Rita. Noonan, R. L. Gash, and Claudia. Buchman. 1993. "Borrowing Against the Future: Children and Third World Indebtedness." Social Forces 71: 629656.

Bradshaw, York and Anna. Wahl. 1991. "Foreign Debt Expansion, the International Monetary Fund, and Regional Variation in Third World Poverty." International Studies Quarterly 35: 251-272.

Brady, David., Yunus Kaya and Jason Beckfield. 2007. "Reassessing the Effect of Economic Growth on Well-Being in Less Developed Countries, 1980-2003.” Studies in Comparative International Development 42: 1-35.

Buchman, Claudia. 1996. "The Debt Crisis, Structural Adjustment, and Women's Education: Implications for Status and Development.” International Journal of Comparative Sociology 37: 5-30.

Buckingham-Hatfield, Susan. 2000. Gender and Environment. New York: Taylor and Francis.

Bulato, Rodolfo. A., and John A. Ross. 2003. "Which Health Services Reduce Maternal Mortality? Evidence from Ratings of Maternal Health Services.” Tropical Medicine and International Health 8: 710-721.

CARE. 2007. The Changing Times: A Plan for Change. Atlanta: CARE.

Clark, John D. 1991. Democratizing Development: The Role of Voluntary Organizations. London: Earthscan Press.

Cook, Cynthia T. 2002. "The Effects of Skilled Health Attendants on Reducing Maternal Deaths in Developing Countries: Testing the Medical Model.” Evaluation and Program Planning 25: 107-116.

Dankelman, Irene and Joan Davidson. 1988. Women and the Environment in the Third World: Alliance for the Future. London: Earthscan Publications.

Bratton, Michael. 1989. "The Politics of Government-NGO Relations in Africa." World Development 17: 569-587.

Bryant, Raymond. L. and Sinead. Bailey. 1997. Third World Political Ecology. London: Routledge.

Clapp, Jennifer. 1998. "Foreign Direct Investment in Hazardous Industries in Developing Countries: Rethinking the Debate.” Environmental Politics 7: 92-113.

Cliff, Julie. 1991. "The War on Women in Mozambique: Health Consequences of South African Destabilization, Economic Crisis, and Structural Adjustment.” Pgs. 15-44 in Women and Health in Africa, edited by M. Turshen. Trenton: Africa World Press.

Dyches, Hayne. and Beth Rushing. 1996. "International Stratification and the Health of Women: An Empirical Comparison of Alternative Models of World-System Position.” Social Science and Medicine 43: 1063-1072.

Evans, Peter. 1979. Dependent Development: The Alliance of Multinational, State, and Local Capital in Brazil. Princeton: Princeton University Press.

Food and Agriculture Organization. 2008. FAOSTAT Online Statistical Service. Rome: Food and Agricultural Organization.

Fowler, Alan. 1991. "The Rise of Non-Governmental Organizations in Changing State-Society Relations: Perspectives from Eastern and Southern Africa.” Development Policy Review 9: 53-84.

Frank, Andre. G. 1967. Capitalism and Underdevelopment in Latin America. New York: Monthly Review Press. 
Frank, David. J., Ann. Hironaka, and Evan. Schofer. 2000. “The Nation-State and the Natural Environment over the Twentieth Century." American Sociological Review 65: 96-116.

Frank, David. J. 1999. “The Social Bases of Environmental Treaty Ratification.” Sociological Inquiry 69: 523-550.

Freedom House. 1997. Freedom in the World: 1996-1997. New York: Freedom House.

George, Susan. 1992. The Debt Boomerang. Boulder: Pluto Press.

Hafner-Burton, Emile M. and Kiyo. Tsutsui. 2005. "Human Rights in a Globalizing World: The Paradox of Empty Promises.” American Journal of Sociology 110: 1373-1411.

Hertz, Erica, James R. Herbert, and Joan Landon. 1994. "Social and Environmental Factors and Life Expectancy, Infant Mortality, and Maternal Mortality Rates: Results of a CrossNational Comparison.” Social Science and Medicine 39: 105-114

Hurst, Philip. 1990. Rainforest Politics. London: Zed Books.

Inoue, Keiko and Gili. Drori. 2006. "The Global Institutionalization of Health as a Social Concern: Organizational and Discursive Trends.” International Sociology 21: 199-219.

Jaccard, James J. and Robert Turrisi. 2001. Interaction Effects in Multiple Regression. Thousand Oaks: Sage Publications.

Jorgenson, Andrew. K. 2009. "Foreign Direct Investment and the Environment, the Mitigating Influence of Institutional and Civil Society Factors, and Relationships between Industrial Pollution and Human Health: A Panel Study of Less-Developed Countries.” Organization \& Environment 22: 135-157.

Jorgenson, Andrew. K., Christopher. Dick, and Matthew. Mahutga. 2007. "Foreign Investment Dependence and the Environment: An Ecostructural Approach.” Social Problems 54: 371-394.

Jorgenson, Andrew. K. 2003. "Consumption and Environmental Degradation: A Cross-National Analysis of the Ecological Footprint.” Social Problems 41: 279-288.

Karliner, Joshua. 1997. The Corporate Planet. San Francisco: Sierra Club Books.

Keck, Margaret E. and Kathryn Sikkink. 1998. Activists Beyond Borders. Ithaca: Cornell University Press.

Kelly, William R. and Philip Cutright. 1980. "Modernization and Demographic Transition: Cross-Sectional and Longitudinal Analysis of a Revised Model.” Sociological Focus13: 315-326.

Kitschelt, Herbert. 1986. "Political Opportunity Structures and Political Protest: Anti-Nuclear Movements in Four Democracies.“ British Journal of Political Science 16: 57-85.

Lena, Hugh and Bruce. London. 1993. "The Political and Economic Determinants of Health Outcomes: A Cross-National Analysis.” International Journal of Health Services 23: 585-602.

Leonard, H. Jeffrey. 1988. Pollution and the Struggle for World Product: Multinational Corporations, the Environment, and International Comparative Advantage. Cambridge: Harvard University Press.

Lewis, Tammy L. 2000. "Transnational Conservation Movement Organizations: Shaping the Protected Area Systems of Less Developed Nations.” Mobilization 5: 105-123.

London, Bruce and Ross, Robert .J.S. 1995. "The Political Sociology of Foreign Direct Investment: Global Capitalism and Capital Mobility, 1965-1980.” International Journal of Comparative Sociology 36: 198-219. 
London, Bruce and Bruce Williams. 1990. "National Politics, International Dependency, and Basic Needs Provision: A Cross-National Analysis.” Social Forces 69: 564-584.

London, Bruce. 1988. "Dependence, Distorted Development, and Fertility Trends in Non-Core Nations: A Structural Analysis of Cross-National Data.” American Sociological Review 53: 606-618.

McCarthy, James and Deborah Maine. 1992. “A Framework for Analyzing the Determinants of Maternal Mortality." Studies in Family Planning 23: 23-33.

McMichael, Philip. 2004. Development and Social Change: A Global Perspective. New York: Pine Forge Press.

Menard, Scott W. 2002. Longitudinal Research. Thousand Oaks: Sage Publications.

Mercer, A. M., N. Uddin, N. L. Huq, F. Haseen, M. H. Khan, and C. P. Larson. 2006. "Validating Neo-Natal Mortality and Use of Non-Governmental Organization Reproductive Health Outreach Service in Rural Bangladesh.” Studies in Family Planning 37: 111-122.

Mercer, A., M. H. Khan, M. Daulatuzzaman, and J. Reid. 2004. "Effectiveness of a NonGovernmental Organization Primary Health Care Program in Rural Bangladesh: Evidence form the Management Information System.” Health Policy and Planning 19: 187-198.

Midlarsky, Manus I. 1998. "Democracy and the Environment: An Empirical Assessment. Journal of Peace Research 35: 341-361.

Mohan, Giles. 2001. “The Environmental Impacts of Adjustment.” Pp.95-117 in Structural Adjustment: Theory, Practice, and Impacts edited by G. Mohan, E. Brown, B. Milward, and A. B. Zack-Williams. New York: Routledge.

Moon, Bruce and William Dixon. 1985. "Politics, State, and Basic Human Needs: A CrossNational Study.” American Journal of Political Science 29: 6661-6694.

Newell, Peter. 2000. "Environmental NGOs and Globalization: The Governance of TNCs.' In R. Cohen and S. M. Rai, eds., Global social movements. London: Athlone Press.

Otchere, Susan and Elizabeth. Ransom. 2006. "Bringing Care Closer to Mothers and Newborns: Using the Gap Analysis Tool to Develop a Household to Hospital Continuum of Care.” Wesport: Save the Children.

Paxton, Pamela. 2002. "Social Capital and Democracy: An Interdependent relationship." American Sociological Review 67: 254-77.

Payne, Rodger A. 1995. "Freedom and the Environment." Journal of Democracy 6: 41-55.

Peet, Richard. 2003. The Unholy Trinity: The International Monetary Fund, World Bank, and World Trade Organization. London: Zed Books.

Polity IV Project. 2005. Polity IV Project: Political Regime Characteristics and Transitions. College Park: University of Maryland.

Rice, James. 2008. "Material Consumption and Social Well-Being within the Periphery of the World Economy: An Ecological Analysis of Maternal Mortality." Social Science Research 37: 1292-1309.

Rich, Bruce. A. 1994. Mortgaging the Earth: The World Bank, Environmental Impoverishment, and the Crisis of Development. Boston: Beacon Press.

Robinson, Jane A. and Heather Wharrad. 2001. “The Relationship between Attendance at Birth and Maternal Mortality Rates: An Exploration of United Nations Data Sets Including 
Ratios of Physicians and Nurses to Population.” Journal of Advanced Nursing 34: 445455.

Ross, Robert J. S. and Ken. Trachte. (1990). Global Capitalism: The New Leviathan. Albany: State University of New York Press.

Rostow, Walter. W. 1990. The Stages of Economic Growth: A Noncommunist Manifesto. London: Cambridge University Press.

Royston, Erica and Sue Armstrong. 1989. Preventing Maternal Deaths. Geneva: World Health Organization.

Schafer, Mark J. 1999. "International Non-Governmental Organizations and Third World Education in 1990: A Cross-National Study.” Sociology of Education 72: 69-88.

Schofer, Evan and Ann Hironaka. 2005. "The Effects of World Society on Environmental Outcomes.” Social Forces 84: 25-47.

Shandra, John M. 2007. "The World Polity and Deforestation: A Cross-National Analysis.” International Journal of Comparative Sociology 48: 5-28.

Shandra, John M., Carrie L. Shandra, and Bruce London. 2008. "Women, Non-Governmental Organizations, and Deforestation: A Cross-National Study." Population and Environment 38: 48-72.

Shandra, John M., Eran Shor, and Bruce London. 2008. "Debt, Structural Adjustment, and Organic Water Pollution: A Cross-National Analysis.” Organization and Environment 21: 38-55.

Shandra, John M., Bruce London, and Robert J. S. Ross. 2003. "Global Capitalism and the Flow of Foreign Direct Investment to Non-Core Nations: A Quantitative, Cross-National Analysis.” International Journal of Comparative Sociology 44: 199-238.

Shandra, John M., Jenna E. Nobles, Bruce London, and John B. Williamson. 2003. "Dependency, Democracy, and Infant Mortality: A Cross-National Analysis of Developing Nations.” Social Science and Medicine 59: 321-333.

Shen, Che and John B. Williamson. 2001. "Accounting for Cross-National Differences in Infant Mortality Decline (1965-1991) Among Less Developed Countries: Effects of Women's Status, Economic Dependency, and State Strength.” Social Indicators Research 53: 257288.

Shen, Che and John B. Williamson. 1999. "Maternal Mortality, Women’s Status, and Economic Dependency in Less Developed Countries: A Cross-National Analysis.” Social Science and Medicine 49: 197-214.

Shiffman Jeremy. 2000. “Can Poor Countries Surmount High Maternal Mortality?” Studies in Family Planning 31: 274-289.

Smith, Jackie. 1995. “Transnational Political Processes and the Human Rights Movement.” In L. Kriesberg, M. Dobkowski, and I. Walliman (eds.), Research in Social Movements, Conflict, and Change, 185-220. Greenwood: JAI.

Sullivan, Gerard. 1983. "Uneven Development and National Income Inequality in Third World Countries. A Cross-National Study of the Effects of External Economic Dependency.” Sociological Perspectives 26: 201-231.

Sundari, T. K. 1992. "The Untold Story: How the Health Care Systems in Developing Countries Contribute to Maternal Mortality.” International Journal of Health Services 22: 513-528.

Tarrow, Sydney. 1994. Power in movement: Social Movements, Collective Action, and Politics. Cambridge: Cambridge University Press. 
Wiktorowicz, Quintan. 2002. "The Political Limits to Non-Governmental Organizations in Jordan.” World Development 30: 77-93.

Walton, John and Charles Ragin. 1990. "Global and National Sources of Political Protest: Third World Responses to the Debt Crisis.” American Sociological Review 55: 875-90.

Williams, Mariama. 2007. Gender and Trade: Implications for Women. Rio de Janeiro: International Gender and Trade Network.

Woptika, Christine M. and Francisco Ramirez. 2008. "World Society and Human Rights: An Event History Analysis of the Convention on the Elimination of All Forms of Discrimination against Women.” Pgs. 303-343 in The Global Diffusion of Markets and Democracy. B. Simmons. Dobbin, and G. Garrett (eds.).Cambridge: Cambridge University Press).

World Bank. 2003. World Development Indicators. New York: Compact Disk.

World Bank. 2001. World Development Report. New York: Oxford University Press.

World Health Organization. 2007. Maternal Mortality in 2005. Geneva.: World Health Organization.

World Health Organization. 2006. Global Health Atlas. Geneva: World Health Organization.

World Health Organization. 2002. WHO and Civil Society: Linking for Better Health. Geneva: World Health Organization. 